\title{
Efficacy of Coconut Oil (Cocos nucifera L.) Fortification on Lipid Profile of Rats with
} Induced Hypothyroidism

\section{Heba H. Mohammed, Naeem M. Rabeh and Mohammed H. Haggag}

Nutrition and Food Science Department, Faculty of Home Economics, Helwan University, Cairo, Egypt Received: 10 March 2020 / Accepted 20 April 2020 / Publication date: 20 May 2020

\begin{abstract}
The aim of the present study was to investigate the effect of coconut oil fortification on serum lipid profile of rats with induced hypothyroidism. Thirty adult male albino rats (Sprague-Dawley strain), weighing about $(200 \pm 10 \mathrm{~g})$ were divided randomly into two main groups as follow: the first group (ve control, $n=6$ rats) was fed on basal diet. The second group (24rats) were fed on basal diet and injected with 6-n-propyl-2-thiouracil (PTU) (10 mg/kg Body weight i.p.) for 15 days to induce hypothyroidism, then divided into 4 subgroups. subgroup 1 (+ve control) fed on basal diet only. Subgroups 2, 3 and 4 were fed on basal diet fortified with 5, 7.5 and $10 \%$ coconut oil, respectively. At the end of the experimental period (six weeks), animals were scarified for blood collection. Thyroid hormones (FT3 and FT4), thyroid-stimulating hormone (TSH), low-density lipoprotein (LDL), high-density lipoprotein (HDL), very low-density lipoprotein (VLDL), total cholesterol (TC), triglyceride (TG), malondialdehyde (MDA) and catalase (CAT) were determined. Hypothyroidimic rats which were fed a diet fortified with different levels of coconut oil had significant $(\mathrm{P}<0.05)$ decreased on serum TSH, VLDL-c, LDL-c ,TC ,TG and MDA levels while serum thyroid hormones (FT3 and FT4), HDL-c and CAT were significantly $(\mathrm{P}<0.05$ increased compared with $+\mathrm{ve}$ control group. It could be suggested that fortification with coconut oil could be used as a suitable therapy for hypothyroidimic patients.
\end{abstract}

Keywords: coconut oil, hypothyroidism, thyroid hormones, lipid profile, rats

\section{Introduction}

The thyroid gland is an endocrine gland in the neck, consisting of two lobes connected by an isthmus. It is responsible for secreting hormones that regulates body metabolism (Skarulis and Stack, 2015). The hormones also have many other effects including those on development. The thyroid hormones triiodothyronine (T3) and thyroxin (T4) are created from iodine and tyrosine. The thyroid also produces the hormone calcitonin, which plays a role in calcium homeostasis (Hall and John, 2011).

Hypothyroidism, called underactive thyroid or low thyroid, is a disorder of the endocrine system in which the thyroid gland does not produce enough thyroid hormone. It can cause a number of symptoms, such as poor ability to tolerate cold, a feeling of tiredness, constipation, depression and weight gain (NIDDKD, 2013). Thyroid dysfunction is associated with changes in body weight, composition and total and resting energy expenditure independently of physical activity. Moreover, weight gain often develops after treatment of thyroid dysfunction. Hypothyroidism is frequently associated with weight gain and decreased metabolic rate (Asvold et al., 2009).

Coconut oil (Cocos nucifera L.), is an edible oil extracted from the kernel or meat of mature coconuts harvested from the coconut palm (Berlin, 2015). It is a colorless to brown-yellow edible oil derived from mature coconuts (Babu et al., 2014). Coconut oil comprises $99.9 \%$ fatty acids; of these, $91.9 \%$ are saturated fatty acids, $6.4 \%$ are monounsaturated fatty acid acids and $1.5 \%$ are polyunsaturated fatty acids, and coconut oil contains no dietary cholesterol (PHE, 2015) . Coconut oil fatty acids are lauric, myristic and palmitic acids. Virgin coconut oil has been found to contain up to seven times higher concentrations of polyphenols than standard coconut oil, with total polyphenol contents of up to $80 \mathrm{mg}$ gallic acid equivalents $/ 100 \mathrm{~g}$ oil reported in virgin coconut (Marina et al., 2009).Coconut oil has been renowned for its medicinal and nutritional value. Virgin coconut oil is rich in medium chain fatty acids, phenolic, and polyphenols which made it beneficial as an antioxidant source (Chew, 2019).

Studies on the biological effects of coconut oil have proven that it ameliorates oxidative stress by boosting the antioxidant defense system, mopping up free radicals and reducing lipid peroxidation

Corresponding Author: Heba H. Mohammed, Nutrition and Food Science Department, Faculty of Home Economics, Helwan University, Cairo, Egypt. E-mail: hebahamdy3333@gmail.com 
(Dosumu et al., 2010). In recent years, coconut oil has emerged as the heart healthy alternative to butter. Researchers also described coconut oil with antibacterial and antifungal properties when used as a topical treatment on human skin and hair (Vaughn et al., 2018).It has also been reported to suppress microbial and viral activities (Van Immerseel et al., 2004), promote weight loss and enhance thyroid function (Takeuchi et al., 2008 ). Therefore, this study was conducted to evaluate the efficacy of coconut oil fortification on lipid profile of hypothyroidimic rats.

\section{Materials and Methods}

\section{Materials:}

Coconut oil was purchased from Agriculture Research Center, Giza, Egypt.

Casein, Cellulose, Vitamins, Choline Bitartrate and L-cysteine were obtained from the Global Company for Chemicals Trading, Cairo, Egypt. Minerals and formalin were purchased from El-Gomhoria Company, Cairo, Egypt. Propylthiouracil (PTU) was obtained from Amoun Pharmaceutical Company, El-Obour City, Cairo, Egypt. Kits for blood analysis were purchased from Gama Trade Company for Chemicals, Cairo, Egypt. Rats were purchased from Experimental Animals' Station, Agricultural Research Center, Giza, Egypt.

\section{Methods:}

\section{Induction of Hypothyroidism in Rats}

Propylthiouracil was used for inducing hypothyroidism in this study. Hypothyroidism was induced in normal healthy adult male rats according to Sener et $a l$. (2006) using PTU (10 mg/kg BW/day ) by intraperitoneal (i.p) injection for 15 days. Propylthiouracil injections were repeated once daily. Then, blood samples were obtained from eyes by capillary tube, centrifuged to obtain serum, which was analyzed to compare the values of serum (FT3, FT4 and TSH) to the negative control rats. Hypothyroidism is defined as lower serum FT3, FT4 and higher TSH (Dons and Frank 2009).

\section{Diet Composition and Experimental Animal Design}

The basal diet was formulated according to AIN-93M diet (Reeves et al., 1993). After acclimatization period (7days), rats were divided into two main groups. The first main group $(n=6)$ was fed on the basal diet during the experimental period (six weeks) and kept as a negative control (-ve). The rest of the animals $(n=24)$ were injected with PTU for hypothyroidism induction as mentioned before. Hypothyroidimic groups were divided into four subgroups (6 rats each) and were fed on the following diet schema for four weeks:

The remainder rats $(n=24)$ were assigned to one of the following diet scheme for four weeks as follow: Subgroup (1) were fed on basal diet (positive control. Subgroups (2, 3 and 4) were fed on basal diet and fortified with $5 \%, 7.5 \%$ and $10 \%$ coconut oil respectively.

At the end of the experimental period, rats were fasted overnight before sacrificing and the blood samples were collected from each rat and were centrifuged to obtain serum.

\section{Biological Evaluation:}

Feed intake (FI) was determined while Feed efficiency ratio (FER) and body weight gain percent (BWG \%) was calculated according to Chapman et al. (1959). Body mass index (BMI) was determined according to Shabbir et al. (2016).

\section{Biochemical Analysis of Serum:}

Free triiodothyronine (FT3), free thyroxin (FT4) and Thyroid-stimulating hormone (TSH) were determined according to the method described by (Shamsian et al., 2016). Serum total cholesterol (TC), triglyceride (TG) and high density lipoprotein cholesterol (HDL-C) were determined according to Richmond, (1973); Wahlefeld, (1974) and Albers et al., (1983), respectively. Regarding to serum low density lipoprotein cholesterol (LDL-C) and very low density lipoprotein cholesterol (VLDL-C) were calculated according to Friedewald et al., (1972). Malondialdehyde (MDA) and Catalase (CAT) were determined according to Draper and Hadley, (1990) and Aebi, (1984), respectively. 


\section{Statistical Analysis:}

Results were expressed as the mean \pm standard deviation (SD). Data were statistically analyzed for variance using "ANOVA" test at $\mathrm{P} \leq(0.05)$ by SPSS statistical software, version 20 was used for these calculations (Armitage and Berry, 1987).

\section{Results}

The effect of diet fortified with coconut oil on FI, BWG\%, FER and BMI are shown in Table (1). Rats of positive control group with mean feed intake was decreased when compared with negative control rats. All tested groups had mean values higher than positive control group. Regarding to BWG $\%$, during the experiment, positive control group showed significant loss in body weight $(\mathrm{P} \leq 0.05)$ compared to the negative control group. Body weight gain values of hypothyroidimic rats fed on diets fortified with coconut oil $5,7.5$ and $10 \%$ were significantly increased $(p \leq 0.05)$ compared to that of positive control group in the following magnitude of increasing order. Coconut oil fortified with 10 $\%$ induced the better weight gain as no significant difference was observed between this level and that value of the control negative group.

Regarding FER, positive control group was significantly lower than the negative control $(\mathrm{P} \leq$ 0.05). Hypothyroidimic rats fed on diets fortified with coconut oil at the three levels $(5,7.5$ and $10 \%)$ showed significant increase in FER compared to the positive control group. The greatest improvement was observed in the hypothyroidimic group received $10 \%$ coconut oil as no significant difference was observed between this level and that value of the control negative group.

Table 1: Effect of diet fortified with coconut oil on FI, BWG\%, FER and BMI of hypothyroidimic rats

\begin{tabular}{lllll}
\hline \multicolumn{1}{c}{ Parameters } & FI (g/d) & BWG (\%) & FER & BMI(g/cm $\left.{ }^{\mathbf{2}}\right)$ \\
\hline Croups & 20.00 & $29.06 \pm 5.15^{\mathrm{a}}$ & $0.02 \pm 0.001^{\mathrm{a}}$ & $0.592 \pm 0.058^{\mathrm{a}}$ \\
Control (-ve) & 15.00 & $14.91 \pm 4.30^{\mathrm{c}}$ & $0.013 \pm 0.002^{\mathrm{c}}$ & $0.533 \pm 0.031^{\mathrm{d}}$ \\
$\mathbf{5 \%}$ Coconut oil & 17.00 & $18.442 .67^{\mathrm{c}}$ & $0.014 \pm 0.003^{\mathrm{c}}$ & $0.554 \pm 0.035^{\mathrm{c}}$ \\
$\mathbf{7 . 5 \%}$ \%oconut oil & 19.00 & $24.20 \pm 5.03^{\mathrm{b}}$ & $0.016 \pm 0.002^{\mathrm{b}}$ & $0.562 \pm 0.029^{\mathrm{b}}$ \\
$\mathbf{1 0 \%}$ Coconut oil & 20.00 & $28.17 \pm 6.07^{\mathrm{a}}$ & $0.02 \pm 0.004^{\mathrm{a}}$ & $0.579 \pm 0.027^{\mathrm{b}}$ \\
\hline
\end{tabular}

Mean values are expressed as means \pm SD.

Means with different superscript letters in the same column are significantly different at $\mathrm{P} \leq 0.05$.

Results revealed also that the BMI of the positive control group was significantly lower than that of negative control group $(\mathrm{P} \leq 0.05)$. Hypothyroidimic rats fed on diets fortified with coconut oil at the three levels $(5,7.5$ and $10 \%)$ showed significant increase in BMI compared to the positive control group. The greatest improvement of body mass index was observed in the hypothyroidimic group received $10 \%$ coconut oil.

Results of serum FT3 and FT4 and TSH levels are illustrated in Table (2). Both of serum FT3 and FT4 concentrations were significantly $(\mathrm{P} \leq 0.05)$ decreased as a result of PTU injection compared with the negative control group. However, both serum FT3 and FT4 concentration in hypothyroidimic rats were significantly $(\mathrm{P} \leq 0.05)$ increased after following the fortification of the different levels of coconut oil compared to the positive control group.

Table 2: Effect of diet fortified with coconut oil on serum thyroid hormones of hypothyroidimic rats

\begin{tabular}{|c|c|c|c|}
\hline Parameter & FT3 (pg/dl) & FT4 (ng/dl) & TSH (ng/ml) \\
\hline Control (-ve) & $5.05 \pm 0.14^{\mathrm{a}}$ & $2.07 \pm 0.15^{\mathrm{a}}$ & $1.15 \pm 0.004^{\mathrm{d}}$ \\
\hline Control (+ve) & $3.36 \pm 0.81^{\mathrm{c}}$ & $1.20 \pm 0.09^{\mathrm{c}}$ & $3.39 \pm 0.06^{\mathrm{a}}$ \\
\hline $5 \%$ Coconut oil & $3.47 \pm 0.15^{\mathrm{c}}$ & $1.28 \pm 0.02^{\mathrm{c}}$ & $3.30 \pm 0.09^{\mathrm{a}}$ \\
\hline $7.5 \%$ Coconut oil & $4.09 \pm 0.27^{b}$ & $1.71 \pm 0.08^{b}$ & $2.57 \pm 0.08^{b}$ \\
\hline $10 \%$ Coconut oil & $4.63 \pm 0.19^{\mathrm{a}}$ & $1.97 \pm 0.05^{\mathrm{a}}$ & $1.96 \pm 0.02^{c}$ \\
\hline
\end{tabular}

Mean values are expressed as means \pm SD.

Means with different superscript letters in the same column are significantly different at $\mathrm{P} \leq 0.05$. 
The most pronounce improvement in FT3 and FT4 activities were observed at the group of hypothyroidimic rats fortified with $10 \%$ coconut oil in the diet as no significant difference was observed between these levels and that values of the control negative group. The serum level of TSH was increased significantly $(\mathrm{P} \leq 0.05)$ in the hypothyroidimic control positive group compared to the negative control group. Fortification with coconut oil in the diet at the three different levels to hypothyroidimic rats resulted in significant $(\mathrm{p} \leq 0.05)$ decrease in TSH levels compared to the positive control group. Interestingly, the results revealed that the most pronounced increased in TSH level was observed when rats were fed on diet fortified with $10 \%$ coconut oil.

Table (3) illustrates the effect of diet fortified with coconut oil on serum lipid profile of hypothyroidimic rats. Results revealed that LDL,VLDL, TC and TG concentrations were significantly increased as a result of hypothyroidismic induction with mean values of $52.06 \pm 12.79 \mathrm{mg} / \mathrm{dl}$, $28.38 \pm 2.34 \mathrm{mg} / \mathrm{dl}, 196.18 \pm 24.59 \mathrm{mg} / \mathrm{dl}$ and $141.92 \pm 21.69 \mathrm{mg} / \mathrm{dl}$, respectively compared with the normal control group fed normal diet $39.37 \pm 13.04 \mathrm{mg} / \mathrm{dl}, 22.78 \pm 1.61 \mathrm{mg} / \mathrm{dl}, 187.25 \pm 10.64 \mathrm{mg} / \mathrm{dl}$ and $113.92 \pm 18.07 \mathrm{mg} / \mathrm{dl}$,respectively. While serum HDL concentrations were significantly decreased as a result of hypothyroidismic induction with mean value of $115.16 \pm 14.09 \mathrm{mg} / \mathrm{dl}$ compared with the normal control group $128.43 \pm 16.67 \mathrm{mg} / \mathrm{dl}$.

The levels of HDL significantly increased $(\mathrm{p} \leq 0.05)$ when hypothyroidismic groups fed on diet fortified with coconut oil at $5,7.5$ and 10\% levels of intake compared with the positive control group. These values were $117.15 \pm 15.84 \mathrm{mg} / \mathrm{dl}, 121.83 \pm 15.08 \mathrm{mg} / \mathrm{dl}$ and $125.03 \pm 15.61 \mathrm{mg} / \mathrm{dl}$ vs. $128.43 \pm 16.67 \mathrm{mg} / \mathrm{dl}$, respectively. The highest improvement for HDL was observed at the group that fed on $10 \%$ of coconut oil, while the lowest mean value was observed at the group that fed on $5 \%$ of coconut oil compared with the negative control group.

While the levels of LDL,VLDL,TC and TG significantly decreased $(p \leq 0.05)$ when hypothyroidismic groups fed on diets fortified with coconut oil at $5,7.5$ and $10 \%$ levels of intake compared with the positive control group with mean values of $49.98 \pm 12.99 \mathrm{mg} / \mathrm{dl}, 44.65 \pm 4.83 \mathrm{mg} / \mathrm{dl}$ and $41.47 \pm 10.96 \mathrm{mg} / \mathrm{dl}$, respectively for $\mathrm{LDL}, 26.03 \pm 2.08 \mathrm{mg} / \mathrm{dl}, 24.53 \pm 1.64 \mathrm{mg} / \mathrm{dl}$ and $23.42 \pm$ $1.08 \mathrm{mg} / \mathrm{dl}$, respectively for VLDL , $193.30 \pm 37.55 \mathrm{mg} / \mathrm{dl}, 191.35 \pm 11.84 \mathrm{mg} / \mathrm{dl}$ and $189.01 \pm 17.84$ $\mathrm{mg} / \mathrm{dl}$, respectively for TC , $130.18 \pm 15.41 \mathrm{mg} / \mathrm{dl}, 122.67 \pm 7.87 \mathrm{mg} / \mathrm{dl}$ and $117.12 \pm 22.66 \mathrm{mg} / \mathrm{dl}$, respectively for $\mathrm{TG}$.

The most pronounce improvement in LDL, TC and TG concentrations were observed in the groups of hypothyroidismic rats fed diet fortified with $10 \%$ coconut oil compared with the normal control group. Also, observed that there were no significant differences in LDL, TC and TG for this group compared to negative control group. Likewise, serum VLDL concentration results showed that the best improvement was observed in the group of hypothyroidismic rats fed diet fortified with $10 \%$ coconut oil compared with the normal control group. The highest improvement for lipid profile was observed at the group that fed on $10 \%$ of coconut oil.

Table 3: Effect of diet fortified with coconut oil on serum lipid profile of Hypothyroidimic rats

\begin{tabular}{lllrll}
\multicolumn{1}{c}{ Parameters } & HDL & LDL & VLDL & TC & TG \\
Groups & & & $(\mathbf{m g} / \mathbf{d l})$ & \\
\hline Control (-) & $128.43 \pm 16.67^{\mathrm{a}}$ & $39.37 \pm 13.04^{\mathrm{d}}$ & $22.78 \pm 1.61^{\mathrm{c}}$ & $173.65 \pm 10.64^{\mathrm{c}}$ & $113.92 \pm 18.07^{\mathrm{c}}$ \\
Control (+) $_{\mathbf{5 \%} \text { Coconut oil }}$ & $115.16 \pm 14.09^{\mathrm{e}}$ & $52.06 \pm 12.79^{\mathrm{a}}$ & $28.38 \pm 2.34^{\mathrm{a}}$ & $194.18 \pm 24.59^{\mathrm{a}}$ & $141.92 \pm 21.69^{\mathrm{a}}$ \\
$\mathbf{7 . 5} \%$ Coconut oil $^{\mathbf{1 0} \% \text { Coconut oil }}$ & $121.83 \pm 15.84^{\mathrm{d}}$ & $49.98 \pm 12.99^{\mathrm{b}}$ & $26.03 \pm 2.08^{\mathrm{b}}$ & $188.30 \pm 37.55^{\mathrm{b}}$ & $130.18 \pm 15.41^{\mathrm{b}}$ \\
\hline
\end{tabular}

Mean values are expressed as means \pm SD.

Means with different superscript letters in the same column are significantly different at $\mathrm{P} \leq 0.05$.

Table (4) illustrates the effect of diet fortified with coconut oil on serum MDA and CAT of hypothyroidimic rats. The mean malondialdehyde concentration of the hypothyroidimic control rats was significantly $(\mathrm{P} \leq 0.05)$ increased compared to the negative control group which representing. When rats were fed on coconut oil at any tested level their serum malondialdehyde concentrations were decreased significantly $(\mathrm{P}<0.05)$ compared with the hypothyroidimic rats. The greatest improvement was observed in the hypothyroidimic group received $10 \%$ coconut oil compared with other groups. 
On the other hand, the level of catalase concentration of the hypothyroidimic control rats was significantly $(\mathrm{P} \leq 0.05)$ decreased compared to the negative control group.

The serum catalase concentration of hypothyroidismic rats administered the tested diets containing the three levels of coconut oil of intake were significantly $(\mathrm{P} \leq 0.05)$ increased compared to the positive control group. The greatest mean value of CAT was observed in the hypothyroidismic group received $10 \%$ coconut oil ,while the lowest mean value was observed in the hypothyroidismic group received $5 \%$ coconut oil compared with the negative control group

Table 4: Effect of diet fortified with coconut oil on serum MDA and CAT of hypothyroidimic rats

\begin{tabular}{lll}
\hline \multicolumn{1}{c}{ Parameters } & MDA $(\boldsymbol{\mu m o l} / \mathbf{d L})$ & CAT $(\mathbf{m M} / \mathbf{L})$ \\
\hline Control (-) & $97.60 \pm 8.98^{\mathrm{e}}$ & $75.53 \pm 4.38^{\mathrm{c}}$ \\
Control (+) & $250.00 \pm 42.22^{\mathrm{a}}$ & $37.00 \pm 3.16^{\mathrm{e}}$ \\
$\mathbf{5 \%}$ Coconut oil & $172.32 \pm 15.25^{\mathrm{b}}$ & $52.32 \pm 3.05^{\mathrm{d}}$ \\
$\mathbf{7 . 5} \%$ Coconut oil & $133.32 \pm 18.37^{\mathrm{c}}$ & $96.33 \pm 11.54^{\mathrm{b}}$ \\
$\mathbf{1 0 \%}$ Coconut oil & $112.32 \pm 9.28^{\mathrm{d}}$ & $110.32 \pm 19.13^{\mathrm{a}}$ \\
\hline
\end{tabular}

Mean values are expressed as means \pm SD.

Means with different superscript letters in the same column are significantly different at $\mathrm{P} \leq 0.05$.

\section{Discussion}

Virgin coconut oil is known to have beneficial health effects. Although it is rich in saturated fatty acids, these saturated fatty acids are easily absorbed and used as energy for metabolism and protects the body from disease (El-Shemy, 2018). Natural oils such as virgin coconut oil (VCO) is evolving as functional foods due to its health promoting pharmacological activities (Famurewa et al., 2017and Ogedengbe et al., 2018).

The current study was mainly focused to investigate the effect of coconut oil for hypothyroidimic rats which injected with PTU. Hypothyroidism is a metabolic disorder which is usually associated with disturbance in FI which is reflected on body weight of individuals (Cadnapaphornchal et al., 2003). In the present study the amount of FI and body weight gain of hypothyroid rats was less than the normal negative control group. These results are in agreement with (Mohamed et al., 2016), who indicated that FI of hypothyroid rats was lower $30.5 \%$ than the negative control rats and body weight gain of hypothyroid rats was lower $38.02 \%$ than the negative control rats.

It is well known that thyroid hormones are necessary for growth. Inducing hypothyroidimic in this study led to a reduction in the body weight of rats, which may be explained by reduced thyroid hormone levels as demonstrated by the present results and confirmed by previous studies carried out on rats (Amara et al., 2010).And, who reported that, compared to control, 14-day-old rats $(\mathrm{n}=48)$, whose mothers received $250 \mathrm{mg}$ of MMI in their drinking water, showed a decrease of $42 \%$ in their body weights.

PTU induction induced hypothyroidism with a reduction in serum levels of FT3 and FT4 and increase in serum TSH level compared to the normal control rats. These results are in agreement with Rabeh and El-Ghandour, (2016) and Negm, (2019). Serum concentrations of thyroid hormones (T3, T4) and TSH are commonly used as reliable indicators of the thyroid function in humans and experimental animals (Kelly, 2000).

Propylthiouracil effects may be due to inhibiting the thyroid hormones synthesis and blocking the transformation of T4 to T3 (Ökten et al., 1996). Deiodinase is strongly inhibited by the anti-thyroid drug PTU (Norris, 2007). As the prohormone T4 is then converted to its biologically active form T3 by iodothyronine deiodinase (Bianco et al., 2002). The reduction of thyroid hormone levels of the present study are in the line with those observed by Khalawi et al., (2013). Furthermore Haiying et al., (2006) who found that hypothyroidimic subjects were diagnosed with biochemical parameters of T3 and T4 below the normal ranges and TSH above the normal range. It was also agreed with results of Zbucki et al., (2007) who found a significant decrease in the plasma concentration of T3 and T4 of HT rats whereas TSH level was significantly increased compared to the negative control rats.

The obtained results are in the line with Negm, (2019) who found that, the supplementation with virgin coconut oil caused significant $(\mathrm{P} \leq 0.05)$ increased in concentration of FT3, FT4 and a significant 
$(\mathrm{P} \leq 0.05)$ decrease in the TSH, compared to the positive control group. Bhanja and Chainy, (2010) reported that hypothyroidism causes oxidative stress in rats. This leads to tissue damage and apoptosis. Dietary fatty acids have marked influence on functioning of thyroid gland (Gupta et al., 2009). Some authors suggest that isoflavones have a moderate or no effect on the role of thyroid (Dillingham et al., 2007). Meanwhile others showed that isoflavones suppress the function of thyroid (Sathyapalan et al., 2011). Gupta et al., (2009) who found that coconut oil fed rabbits had a significant reduction in TSH levels. Rabeh, (2017) who found that, virgin coconut oil, curcumin, vitamin D or their mixture increased the level of thyroid hormones and lowered the level of TSH. Such effects may be due to high content in VCO of polyphenolic and other antioxidants. Rabeh, (2017) and Takeuchi et al., (2008) who reported that coconut oil enhances thyroid functions.

The supplementation with Iron, Zinc, Vit.E and Vit.C significantly $(\mathrm{P}<0.05)$ increased the concentration of thyroid hormones FT4 and FT3 and also caused a significant $(\mathrm{P}<0.05)$ decrease in the mean value of TSH, compared with control positive group. There are several trace elements that are needed for the normal function, synthesis and metabolism of the thyroid gland (Rabeh and El-Ghandour, 2016). Coconut oil is a source of vitamin $E$ and polyphenols (Rabeh, 2017).

Serum levels of TC, TG, LDL and VLDL increased significantly by PTU rat's injection ( $\mathrm{P} \leq 0.05)$ compared with the -ve control group. The fortification of coconut oil caused a significant $(\mathrm{P} \leq 0.05)$ decrease in VLDL, LDL, TC and TG significant compared with the +ve control group. In the same line of Negm, (2019) who reported that, the supplementation with soy oil(SO), VCO and M.oleifera seeds oil MOO caused a significant $(\mathrm{P} \leq 0.05)$ decrease in TC, TG, VLDL-c and LDL-c than the positive control group. Both VCO and (MOO) had nearly the same effect on the determined parameters.

While the levels of HDL increased significantly by PTU injection of rats $(\mathrm{P} \leq 0.05)$ compared with the negative control group and fortification of coconut oil caused a significant $(\mathrm{P} \leq 0.05)$ increased of serum HDL. In the same line, Nazifi et al., (2012). Some investigators have suggested that the increase in kinds of lipid levels in hypothyroidism patients results from the hormones of thyroid influence on lipid metabolism (Ibrahim et al., 1984) .Their possibilities for the metabolism of lipids in hypothyroidism are the presence of lipid activating factors in hypothyroidism and a decrease in hepatic lipase activity (Çelik et al., 2000).

Affecting the metabolism of lipids, hypothyroidism accelerates the process of atherogenesis and increases cardiovascular risk. In obvious hypothyroidism, the number of LDL receptors in the liver reduces and the levels of overall cholesterol and LDL cholesterol in the blood increase. Levels of HDL particles remain normal or even slightly raised as a result of reduced activity of the cholesterol ester transfer protein and hepatic lipase. (Pesić et al., 2007).

Siddalingaswamy et al., (2011), who found that VCO improved lipid profile and antioxidant status by enhancing antioxidant enzyme activity and decreased lipid peroxidation in liver. Rahim et al., (2017) and Rabeh, (2017) who showed that VCO lowered TC, TG, LDL, VLDL and increased HDL. Similar result was consistent with Hima et al., (2019) showed that VCO had hypolipidemic effect on rats which elevated high density lipoprotein cholesterol and reduced level of triacylglycerol. Furthermore, the group supplemented with coconut oil in current analysis showed decreased levels of triglycerides in the other groups, perhaps due to its composition: mainly fatty short and medium chain acids which are transported directly to the liver to undergo $\beta$-oxidation (Ooyama et al., 2008). Moreover, virgin coconut oil increases high density lipoprotein cholesterol and reduces the level of low density lipoprotein cholesterol in serum and tissue (Iranloye et al., 2013).

Antioxidant properties and phenolic compounds as tocophenol and tocotrienol in virgin coconut oil aid in the prevention of many diseases. Increased beta carotene increases the fecal secretion of bile acids and decreases the concentration of lipids (Iranloye et al., 2013). Moreover, virgin coconut oil contains high level of phytosterol. This phytosterol competitively blocks the absorption of cholesterol and increases the fecal excretion of bile acids and neutral sterols thus it improves the circulating lipid profile (Sheriff and Devaki, 2012).

In the present study found that hypothyroidism caused significant increase $(\mathrm{P} \leq 0.05)$ activity of MDA and decrease CAT in rats compared to the negative control group. Also, feeding rats suffering from hypothyroidism fortified with coconut oil led to a significant decreased $(\mathrm{P} \leq 0.05)$ in MDA and increased in CAT levels comparing with the positive control group. These results are agreement with that of Haribabu et al. (2013) and Negm, (2019). 
Also, Famurewa et al. (2018) reported that the level of malondialdehyde, remarkably reduced and activities of hepatic antioxidant enzymes-superoxide dismutase, CAT, and glutathione peroxidase were markedly increased in VCO diet-fed rats. Malondialdehyde is an oxidative stress marker that can be used to measure the extent of lipid peroxidation (Gaweł et al., 2004). In hypothyroid subjects, MDA level was found to be higher in oxidative stress (Lakshmi et al., 2013). Phytoestrogens can play an antioxidant role not only by breaking down reactive oxygen species, but also by stimulating antioxidant enzyme activity (Taha et al., 2014). Marina et al., (2009) and Yeap et al., (2015) demonstrated the antioxidative potential and powerful countermeasures of VCO polyphenols against lipid peroxidation in tissues.

Iranloye et al. (2013) suggested that VCO reduces oxidative stress by boosting the antioxidant defense system, scavenging free radicals and reducing lipid peroxidation another independent study suggested that fresh coconut oil can reduce oxidative stress associated with diabetes mellitus. Famurewa et al. (2018) showed that VCO decreased MDA levels and increased activities of hepatic antioxidant enzymes superoxide dismutase. In addition, blending of $\mathrm{VCO}$ with groundnut oil or olive oil was proven to be effective in inhibiting LDL oxidation, and stimulating the activity of hepatic antioxidant enzymes (Nagaraju and Belur, 2008) .

Virgin coconut oil contains high unsaponifiable lipid components like vitamin E and polyphenols, tocotrienols, tocopherols, $\beta$ carotene and phytosterol in stabilising cell membranes by preventing alterations in membrane lipid polarity and fluidity (Jaarin et al., 2014 and Nevin and Rajamohan, 2010). Marina et al., (2009), estimated the total phenolic content of VCO to be in the range of 7.78-29.18 mg GAE/100 g oil, which is significantly higher than the refined, bleached, and deodorized coconut oil. The major polyphenols in VCO are ferulic acid and p-coumaric acid. Polyphenols are stronger as antioxidants than vitamins $\mathrm{C}$ and $\mathrm{E}$ in vitro on the molar basis (Rice-Evans et al., 1997 and Banfi et al., 2008).

Gastelluccio et al., (1996), reported that ferulic acid was more potent as an antioxidant against LDL oxidation than ascorbic acid. It seems that VCO derives most of its effects from the free-radical scavenging and antioxidant properties of ferulic acid. Virgin coconut oil is rich in polyphenols and these antioxidants may contribute to the increased levels of antioxidant enzymes, which subsequently reduce lipid peroxidation and inflammation in VCO-treated mice (Zakaria et al., 2011) .

In conclusions, fortification with coconut oil at different tested levels improved hypothyroidism specially at $10 \%$ by the reduction the mean value of TSH, VLDL-c , LDL-c ,TC, TG and MDA levels and causing an increase on the value of thyroid hormones (FT3 and FT4), HDL-c and CAT levels. So that, it could be suggested that fortification with coconut oil could be used as a suitable therapy for hypothyroidimic patients.

\section{References}

Aebi, H., 1984. Catalase in Vitro, Methods enzymology, 105: 121 - 126.

Albers N., V. Benderson and G. Warnick, 1983. Enzaymatic determination of high density lipoprotein cholesterol, Selected Methods. Clin. Chem. 10: 91-99.

Amara I., H. Bouaziz, F. Guermazi and N. Zeghal, 2010. Effect of selenium on hypothyroidism induced by methimazole (MMI) in lactating rats and their pups, Acta Biologica Hungarica, 61(2):145157.

Armitage, G.Y. and W.G. Berry, 1987. Statistical methods $7^{\text {th }}$ Ed. Ames., Iowa State University. Press. 39-63.

Asvold, B., T. Bjøro, and L. Vatten, 2009. Association of serumTSH with high body mass differs between smokers and never-smokers. J Clin Endocrinol Metab., 94:5023-5027.

Babu, A., Veluswamy S. and R. Arena, 2014. Virgin coconut oil and its potential cardioprotective effects. Postgraduate Medicine, 126: 76-83.

Banfi, G., E. Iorio and M. Corsi, 2008. Oxidative stress, free radicals and bone remodeling. Clinical Chemistry and Laboratory Medicine, 46(11):1550-1555.

Berlin, 2015. Coconut oil, German Insurance Association.

Bhanja S. and G. Chainy, 2010. PTU-induced hypothyroidism modulates antioxidant defence status in the developing cerebellum. Neuroscience, 28 (3): 251-262. 
Bianco, A., D. Salvatore, B.Gereben, M. Berry and P. Larsen, 2002. Biochemistry, cellular and molecular biology, and physiological roles of the iodothyronine selenodeiodinases. Endocr. Rev., (1)23: 38 .

Cadnapaphornchal, A., Y. Kim, S. K. Gurevich, N. Falk, S. Thurman and W. Schrier, 2003. Urinary Concentrating Defect in Hypothyroid Rats: Role of Sodium, Potassium, 2-Chloride CoTransporter, and Aquaporins. J Am Soc Nephrol., 14: 566-574.

Chapman, D., R. Gastilla and J. Campbell, 1959. Evaluation of protein in foods: 1- A Method for the determination of protein efficiency ratio. Can. J. Biochem. Phys. 37: 679- 86.

Çelik, I., Türkoglu V. and E. Yegin, 2000. Effects of propylthiouracil-induced hypothyroidism on plasma lipid table in rabbits. Turk J Vet Anim Sci., 24, 149-152 .

Chew, Y.L., 2019. The beneficial properties of virgin coconut oil in management of atopic dermatitis. Phcog Rev., 13:24-7.

Dons, F. Robert and Frank H. Wians Jr., 2009. Endocrine and metabolic disorders clinical lab testing manual ( $4^{\text {th }}$ ed.), Boca Raton: CRC Press. P: 10.

Dosumu, O., F. Duru, A. Osinubi, A. Oremosu and C. Noronha, 2010. Influence of virgin coco-nut oil (VCNO) on oxidative stress, serum testosterone and gonadotropic hormones (FSH, LH) in chronic ethanol ingestion. Agriculture and Biology Journal of North America, 1: 1126-1132.

Dillingham, B., B. Mc-Veigh, J. Lampe and A. Duncan, 2007. Soy protein isolates of varied isoflavone content do not influence serum thyroid hormones in healthy young men. Thyroid.17:131-137.

Draper, H. and M. Hadley, 1990. Malondialdehyde determination as index of lipid peroxidation. Methods Enzymol, 186: 421-31.

El-Shemy, M.A., 2018. Antidiabetic and anti-hyperlipidemic effects of virgin coconut oil in rats Egypt. J. Vet. Sci. 49, (2): 111-117.

Famurewa, A., P. Aja, E. Maduagwuna, C. Ekeleme-Egedigwe, O. Ufebe, and S. Azubuike, 2017. Antioxidant and anti-inflammatory effects of virgin coconut oil supplementation abrogate acute chemotherapy oxidative nephrotoxicity induced by anticancer drug methotrexate in rats. Biomedicine and Pharmacotherapy, 96:905-911.

Famurewa, A., C. Ekeleme-Egedigwe, S. Nwali, N. Agbo, J. Obi, and G. Ezechukwu, 2018. Dietary supplementation with virgin coconut oil improves lipid profile and hepatic antioxidant status and has potential benefits on cardiovascular risk indices in normal rats. J Diet Suppl., 15(3): 330-342.

Friedewald, W.T., R.I. Leve, and D.S. Fredrickson, 1972. Estimation of the concentration of low density lipoprotein cholesterol in plasma without use of the preparative ultracentrifuge. Clin Chem., 18:499-502.

Gastelluccio, C., G. Bolwell, C. Gerrish, and C. Rice-Evans, 1996. Differential distribution of ferulic acid to the major plasma constituents in relation to its potential as an antioxidant. Biochemical Journal, 316(2):691-694.

Gawel, S., M. Wardas, E. Niedworok, and P. Wardas, 2004. Malondialdehyde (MDA) as a lipid peroxidation marker. Wiadomosci Lekarskie, 57(9-10): 453-455.

Gupta, V., L. Walia, S. Gupta and N. Bajwa, 2009. Comparison of the effects of coconut oil and soyabean oil on TSH level and weight gain in rabbits. Online J Health Allied Scs. 8:1-7.

Haiying, Y., Y. Yan, Z. Muxun, L. Huiling, Z. Jianhua, W. Hongwei, and C. Katherine, 2006. Thyroid status influence on adiponectin, acylation stimulating protein (ASP) and complement C3 in hyperthyroid and hypothyroid subjects. Nutrition and Metabolism, Bio Med Central, 3 (13):1-8.

Hall, J., and E. John, 2011. Guyton and Hall textbook of medical physiology (12 ${ }^{\text {th }}$ ed.). Philadelphia, ISBN 978- 1-4160-4574-8.

Haribabu, A., V. Reddy, C. Pallavi, A. Bitla, A. Sachan, P. Pullaiah, V. Suresh, P. Rao, and M. Suchitra, 2013. Evaluation of protein oxidation and its association with lipid peroxidation and thyrotropin levels in overt and subclinical hypothyroidism. Endocrine. 44 (1):152-7.

Hima, L., U. Pratap, S. Karrunanithi, K. Ravichandran, R. Vasantharekha and S. Thyaga-Rajan, 2019. Virgin coconut oil supplementation in diet modulates immunity mediated through survival signaling pathways in rats. J Complement Integr Med., 185-196.

Ibrahim, R.E., M.A. Maglad, S.E. Adam, T.E. Mirghanein, and I.A. Wasfi, 1984. The effect of altered thyroid status on lipid metabolism in Nubian goats. Comp. Biochem. Phsyiol., 77 (3): 507-512 .

Iranloye, B., O. Gabriel and M. Olubiyi, 2013. Anti-diabetic and antioxidant effects of virgin coconut oil in alloxan induced diabetic male sprague dawley rats. J of Diab. Melli., 3: 221- 226. 
Jaarin, K ., M. Norliana, Y. Kamisah, M. Nursyafiza and H. Mohd, 2014. Potential role of virgin coconut oil in reducing cardiovascular risk factors. Experimental and Clinical Cardiology. 20(8): 3399-3410.

Kelly, G.S., 2000. Peripheral metabolism of thyroid hormones: a review, Altern Med Rev. 5:306-333.

Khalawi, A.A., A.A. Al-Robai, S.M. Khoja and S.S. Ali, 2013. Can Nigella Sativa Oil (NSO) reverse hypothyroid status induced by PTU in rat? biochemical and histological studies, Life Science Journal, 10(2):802-811.

Lakshmi, L., M. Eli, Z. Doddigarla and K. Suchitra, 2013. Serum lipids and oxidative stress in hypothyroidism. J Adv Res Biol Sci., 5(1):63-6.

Marina, A., Y. Che Man, S. Nazimah, and I. Amin, 2009. Antioxidant capacity and phenolic acids of virgin coconut oil. International Journal of Food Sciences and Nutrition, 60(2):114-123.

Mohamed, A., H. Ibrahim, and N. Rabeh, 2016. Effect of Selenium and Zinc Supplementation on Hypothyroidism in Rats, 53:55.

Nagaraju, A., and L. Belur, 2008. Rats fed blended oils containing coconut oil with groundnut oil or olive oil showed an enhanced activity of hepatic antioxidant enzymes and a reduction in LDL oxidation. Food Chemistry, 108(3):950-957.

NIDDKD, 2013. National Institute of Diabetes and Digestive and Kidney Diseases," Hypothyroidism".

Nazifi, S., M. Saeb, M. Sepehrimanesh, and S. Poorgonabadi, 2012. The effects of wild pistachio oil on serum leptin, thyroid hormones, and lipid profile in female rats with experimental hypothyroidism, Comp Clin Pathol, 21:851-857 .

Negm, S., 2019): Effect of Soybean, Virgin Coconut and Moringa oleifera Seed Oils on the Propylthiouracil Induced Hypothyroidism in Rats, Alexandria Science Exchange Journal, 40(4):650-654.

Nevin, K. and T. Rajamohan, 2010. Effect of topical application of virgin coconut oil on skin components and antioxidant status during dermal wound healing in young rats. Skin Pharmacology and Physiology, 23(6):290-297.

Nevin, K., and T. Rajamohan, 2006. Virgin coconut oil supplemented diet increases the antioxidant status in rats. Food Chemistry, 99(2):260-266.

Norris, D.O., 2007. Vertebrate endocrinology.4th ed. Elsevier Inc.

Ogedengbe, O., E. Naidu, E. Akang, U. Offor, I. Onanuga, A. Peter, and O. Azu, 2018. Virgin coconut oil extract mitigates testicular induced toxicity of alcohol use in antiretroviral therapy. Andrology, 6(4):616-626.

Ökten, A., Z. Mungan and M. Onuk, 1996. A case of propylthiouracil induced hepatotoxicity and hemolytic anemia, Tur J Gastroenterol, 7: 82-85.

Ooyama, K., J. Wu and N. Nosaka, 2008. Combined intervention of medium- chain triacylglycerol diet and exercise reduces body fat mass and enhances energy expenditure in Rats. Journal of Nutritional Science and Vitaminology, 54:136- 141.

Pesić, M., S. Antić, R. Kocić, D. Radojković, and S. Radenković, 2007. Cardiovascular risk factors in patients with subclinical hypothyroidism. Vojnosanit Pregl, 64:749-752.

PHE, Public Health England, 2015. McCance and Widdowson's 'composition of foods integrated dataset' on the nutrient content of the UK food supply. Available at: https://www.gov.uk /government / publications/composition-of-foods-integrated-dataset-cofid.

Rabeh, N.M., and H.A. El-Ghandour, 2016. Effect of iron, zinc, vitamin E and vitamin C supplementation on thyroid hormones in rats with hypothyroidism, International Journal of Nutrition and Food Sciences, 5(3): 201-210.

Rabeh, N.M., 2017. Effect of virgin coconut oil, curcumin and vitamin D supplementation on rats with induced hypothyroidism. Journal of Home Economics, 27(2):1-21.

Rahim, N., S. Lim, V. Mani, A. Majeed, and K. Ramasamy, 2017. Enhanced memory in Wistar rats by virgin coconut oil is associated with increased antioxidative, cholinergic activities and reduced oxidative stress. Pharmaceutical Biology, 55: 825-832.

Reeves, P., H. Forrest and G. Fahey, 1993. AIN-93 purified diets for laboratory rodents: final report of the American institute of nutrition Ad Hoc writing committee on the reformulation of the 76A rodent diet. J. Nutr. 123:1939-1951.

Rice-Evans, C., N. Miller, and G. Paganga, 1997. Antioxidant properties of phenolic compounds. Trends in Plant Science, 2(4):152-159. 
Richmond, N., 1973. Colorimetric determination of total cholesterol and high density lipoprotein cholesterol (HDL-c). Clin. Chem., 19: 1350- 1356.

Sener, G., L. Kabasakal, B. Atasoy, C. Erzik, A. Velioglu-Ögünç, S. Çetinel, G. Contuk, N. Gedik, and B. Yegen, 2006. Propylthiouracil-induced hypothyroidism protects ionizing radiation-induced multiple organ damage in rats, Journal of Endocrinology, 189, 257-269.

Shabbir, F., S. Khan, M. Yousaf, M. Khan, and T. Rajput, 2016. Comparison of effect of high fat diet induced obesity and Subsequent atorvastatin administration on different Anthropometric measures in sprague dawley rats. Pak Armed Forces Med J, 66(5):699-704.

Shamsian, A., K. Ghazvini, M. Sokhtanloo, M. Moghaddam, and R. Vakili, 2016. Which quantitative method in determination of the thyroid hormone levels is more consistent with the clinical symptoms of the thyroid disorders? Comp Clin Path. 25(1):101-6.

Sheriff, S., and T. Devaki, 2012. Lycopene stabilizes lipoprotein levels during D-galactosamine lipopolysaccharide induced hepatitis in experimental rats. Asian Pac. J. Trop. Biomed, 2, 930934.

Siddalingaswamy, M., A. Rayaorth, and F. Khanum, 2011. Anti-diabetic effects of cold and hot extracted virgin coconut oil. Journal of Diabetes Mellitus, 1(4): 118-123.

Skarulis, M. and B. Stack, 2015. Thyroid disease. e-Publication; Office on Women's Health (OWH). U.S. Department of Health and Human Services, Washington DC http: //www.womenshealth .gov/publications /our publications/fact-sheet/thyroid -disease .pdf

Sathyapalan, T., A. Manuchehri, N. Thatcher, A. Rigby, T. Chapman, and E.S. Kilpatrick, 2011. The effect of soy phytoestrogen supplementation on thyroid status and cardiovascular risk markers in patients with subclinical hypothyroidism: a randomized, double-blind, crossover study. J Clin Endocrinol Metab. 96(5):1442-9.

Taha, N., A. Mandour, and M. Lebda, 2014. Antioxidative and cardio-protective effects of ethanolic extract of ginger on triton WR-1339 induced hyperlipidemia in rats. International Journal of Chemical Research, 6(1): 153-158.

Takeuchi, H., S. Sekine, K. Kojima, and T. Aoyama, 2008. The application of medium-chain fatty acids: Edible oil with a suppressing effect on body fat accumulation. Asia Pacific Journal of Clinical Nutrition, 17: 320-324.

Van Immerseel, F., J. Buck, and F. Boyen, 2004. Medium chain fatty acids decrease colonization and invasion through hila suppression shortly after infection of chickens with Salmonella enterica serovar enteritidis. Applied and Environmental Microbiology, 70: 3582-3587.

Vaughn, A.R., A.K. Clark, R.K. Sivamani, and V.Y. Shi, 2018. Natural Oils for Skin- Barrier Repair: Ancient Compounds Now Backed by Modern Science. Am J Clin Dermatol., 19(1): 103-117.

Wahlefeld, A., 1974. Methods of Enzymatic Analysis. Academic Press, Chapter, 5: 1831-1835.

Yeap, S., B. Beh, N. Ali, H. Yusof, W. Ho, S. Koh, N. Alitheen, and K. Long, 2015. Antistress and antioxidant effects of virgin coconut oil in vivo. Exp. Ther. Med., 9 (1):39-42.

Zakaria, Z., M. Somchit, A. Mat Jais, L. Teh, M. Salleh, and K. Long, 2011. In vivo antinociceptive and anti-inflammatory activities of dried and fermented processed virgin coconut oil. Med Princ Pract, 20:231-236.

Zbucki, R., M. Winnicka, B. Sawicki, B. Szynaka, A. Andrzejewska and Z. Puchalski, 2007. Alteration of parafollicular (C) cells activity in the experimental model of hypothyroidism in rats, Folia Histochemica et Cytobiologica, 45(2). 